\title{
Modeling Of Lead Adsorption on Low Cost Adsorbents By Response Surface Methodology
}

\section{Shukla Chamanagowda Patil and Veena Kumara Adi*}

PG department of Environmental Engineering, Department of Civil Engineering,

Bapuji Institute of Engineering Technology Davanagere,

Email:drveena.adi@gmail.com

\section{ABSTRACT}

In the present study we explore the possibility of deploying agricultural waste such as Coirpith and Peanut shell waste as heavy metal (lead) adsorbents from a synthetic media. The adsorption of lead $(\mathrm{Pb})$ was carried out using Response Surface Methodology (RSM). The influence of adsorption factors viz., initial concentration of adsorbate $(\mathrm{Pb})$, adsorbent dosage, and agitation time (Exposure time of adsorbate). A total of 15 runs of experiments were conducted employing the detailed conditions designed by RSM based on Box-Behnken Design. Results as Contour plots and Surface plots were analysed to know the interactions between the factors. Coirpith could absorb a maximum of $99.060 \%$ whereas, a maximum adsorption of 96.27\% was achieved by peanut shell. The experimental values well agreed with the RSM predicted values. Coirpith seems to be better adsorbent over peanut shell. RSM seems to be an ideal tool to undertake adsorption, bio-remedial studies.

Key words: Lead, Adsorption, Response Surface Methodology, Coirpith, Peanut shell.

*Corresponding Author

\section{INTRODUCTION}

Lead is toxic heavy metal having an atomic number of 82 and indicated by $\mathrm{Pb}$ and has been widely used in industries. Excess of lead in drinking water causes anemia, hepatitis (Shakwri et al,; 2012). The Indian discharge limit of $\mathrm{Pb}$ is $1.0 \mathrm{mg} / \mathrm{L}$ and according to World Health Organization (WHO) has set the permissible limit of $\mathrm{Pb}$ in drinking $0.1 \mathrm{mg} / \mathrm{L}$ (Pradeepkumar et al.;2012). Chemical precipitation, electro dialysis, ultrafiltration, Nanofiltration, coagulation flocculation, flotation, reverse osmosis, ion exchange, these are the techniques used for the optimization of heavy metals but these methods are uneconomical and not efficient (Neeta Singh et al;2016). The aim of this project is to optimize the $\mathrm{Pb}$ in the solution by adsorption process using naturally available low cost adsorbents. There are many low cost adsorbent materials available for the treatment of heavy metals viz., maize bran (K.K Singh et,al.;2006) for removal of lead, coconut husk (I.E.Agbozu et al.;2014) for adsorption of $\mathrm{Cu}, \mathrm{Pb}$, $\mathrm{Fe}, \mathrm{Cr}$ and $\mathrm{Cd}$, ground nut shell (SeydaTasar et al.;2014) for Biosorption of $\mathrm{Pb}^{2+}$, tea waste (Sarifah et al.;2015) for adsorption of lead, rice husk (Prabha R.T et al.;2014) for removal of heavy metals, egg shell (PARK Heung Jai et al.;2007) for removal of heavy metals. In the present study coir pith and peanut shell are used as low cost adsorbents for the adsorption of lead 
from aqueous solution.

Coir pith is fibrous material that is extracted from coconut husk.It is having soil conditioning character and used as soil less medium for agricultural purpose. It lignocelluloses material of the plant origin containing cellulose and hemi cellulose content lignin, pectin and waves which acts as binders. It strongly adsorbs liquid and gases as it is honey-comb like structure of the mesocarp tissue which gives high surface area per unit volume. It contains short fibres of about 2 to $13 \%$ of the total cork like particles ranging in size from granular to fine dust. (A.A Essiett.,et al 2011).

Peanut shell is raw material obtained from many oil mill industries, which is having physical properties are bulk density, porosity, $\mathrm{pH}$ and chemical properties are moisture, protein, fat, fibres, cellulose, lignin and ash (F.D.Oliveira et al.;)

Response surface Methodology(RSM) a fraction factorial design it involves a set number of design experiments to obtain an optimal response enable effective medium optimization using limited number of trails and limitations. Nowdays it is widely used for various processes including adsorption studies. Box-Behnken design is part of RSM, where each experimental variable is taken at three levels and the actual value is compared with the predicted response ( $\mathrm{J}$. Aravind., et al 2015).

In this paper, we report that the adsorption of lead onto coir pith and peanut shell by various important process parameters such as agitation time, adsorbent dosage and initial concentration of lead that have significant impact on adsorption capability of coir pith and peanut shell.

The aim of this study is to investigate the feasibility of coir pith and peanut shell as low cost adsorbents during the adsorption of lead $(\mathrm{Pb})$ from synthetic media.

\section{MATERIALS AND METHODS}

\section{Preparation of adsorbate}

A stock solution was prepared by dissolving $1.6 \mathrm{gm}$ of $\mathrm{Pb}\left(\mathrm{No}_{3}\right)_{2}$ in $1000 \mathrm{mlof}$ double distilled water. Further 10ppm, 55ppm and 100ppm were prepared.(Lokendra et al.;).

\section{Preparation of adsorbents}

Coir pith and peanut shell were used as adsorbent material. Coir pith was pretreated as per (OkonOkon et al.;2012) it was boiled with distilled water in order to remove the colour of coir dust and air dried. Peanut shell was collected from oil mill and washed with distilled water; it was pretreated as per (Nordiana et al.;2013). The dried coir pith and peanut shell powder were then treated with sulphuric acid in 1:10 ratio about 2 hours and washed with distilled water till $\mathrm{pH}$ of the solution reached neutral later it was followed by oven dry for 30 minutes with occasional stirring in order to get constant weight (W.S. Wan Ngah et al.;2007).

\section{Batch adsorption studies}

In batch experiment a total of 15 runs were carried out with all varying parameters viz., initial concentration of adsorbate, dosage of adsorbent and agitation time designed by the soft ware. The samples were kept for agitation at speed of $160 \mathrm{rpm}$ and at temperature of $28^{\circ} \mathrm{C}$. Followed by filtration using what's man filter and exposure to AAS analysis. 


\section{Nitric acid -sulfuric acid digestion method:}

It was carried out as per standard protocol (standard method committee 1999, editorial revision 2011. (3030E.1.a method)).Before analysing in AAS the sample digestion should be done. Measured volume of sample has taken and $10 \mathrm{ml}$ of concentrated $\mathrm{HNO}_{3}$ added and heated it on a hot plate untill it becomes 10 to $20 \mathrm{ml}$ and $5 \mathrm{ml}$ of concentrated $\mathrm{HNO}_{3}$ and $10 \mathrm{ml} \mathrm{H}_{2} \mathrm{SO}_{4}$, added again heated it on a hot plate till the dence fumes of $\mathrm{SO}_{3}$ appears. It was cooled and made upto 50ml with distilled water and analysed using AAS.

\section{Calculation}

The \% lead removal, $\mathrm{R}(\%)$, was calculated after each run as follows:

Metal removal (\%) at any instant of time was determined by the following equation:

$\%$ of removal efficiency $=\left(\left(\mathrm{C}_{\mathrm{i}}-\mathrm{C}_{\mathrm{e}}\right) / \mathrm{C}_{\mathrm{i}}\right) * \mathbf{1 0 0}$

Where, $C_{i}$ and $C_{e}$ represent initial and final metal concentration $(\mathrm{mg} / \mathrm{L})$ at any instant of time, respectively.

\section{Box-Behnken Design}

Factors: 3 Replicates: 1

Base runs: 15 Total runs: 15

Base blocks: 1 Total blocks: 1

Centre points: 3

Table 1: Experimental levels of factors in RSM

\begin{tabular}{|l|c|l|c|c|}
\hline Variables & & Units & Low Value & High Value \\
\hline Time & A & Hours & 2 & 24 \\
\hline Amount of adsorbent & B & Gram & 0.2 & 1 \\
\hline $\begin{array}{l}\text { Concentration of adsorbate } \\
\text { (lead) }\end{array}$ & C & ppm & 10 & 100 \\
\hline
\end{tabular}

Table 2: Optimum conditions for experimental plan with values of the Box-Behnken Design for the variables.

\begin{tabular}{|c|l|l|l|}
\hline Run Order & A & B & C \\
\hline 1 & 2 & 1.0 & 55 \\
\hline 2 & 13 & 0.6 & 55 \\
\hline 3 & 13 & 1.0 & 100 \\
\hline 4 & 13 & 1.0 & 10 \\
\hline 5 & 2 & 0.6 & 10 \\
\hline 6 & 13 & 0.2 & 10 \\
\hline 7 & 13 & 0.6 & 55 \\
\hline 8 & 2 & 0.6 & 100 \\
\hline 9 & 24 & 0.6 & 10 \\
\hline 10 & 13 & 0.6 & 55 \\
\hline 11 & 24 & 0.6 & 100 \\
\hline 12 & 24 & 0.2 & 55 \\
\hline 13 & 2 & 0.2 & 55 \\
\hline 14 & 24 & 1.0 & 55 \\
\hline 15 & 13 & 0.2 & 100 \\
\hline
\end{tabular}


The above table shows the Box-Behnken Design obtained from RSM a total of 15 runs obtained by varying all the dependent variables such initial concentration of lead, Amount of adsorbent and contact time (Mohammad et al., 2016).

\section{RESULT AND DISCUSSION}

\section{Box-Behnken Design}

$\mathrm{A}=$ Time

$\mathrm{B}=$ Amount of adsorbent

$\mathrm{C}=$ Concentration of lead

Table 3: Predicted values obtained from the design for coir pith and peanut shell

\begin{tabular}{|l|l|l|l|l|l|l|l|}
\hline \multirow{2}{*}{ Runs } & A & \multirow{2}{*}{ B } & C & \multicolumn{2}{|c|}{ Coir pith } & \multicolumn{2}{c|}{ Peanut shell } \\
\hline 1 & & & & & & \\
\hline 2 & 13 & 0.2 & 55 & 54.160 & 59.238 & 57.6 & $61 . .4987$ \\
\hline 3 & 2 & 0.6 & 55 & 82.490 & 82.490 & 65.67 & 65.6700 \\
\hline 4 & 2 & 1.0 & 55 & 89.780 & 84.702 & 86.67 & 82.7712 \\
\hline 5 & 13 & 0.6 & 55 & 82.490 & 82.490 & 65.67 & 68.6700 \\
\hline 6 & 24 & 1.0 & 55 & 89.810 & 85.183 & 88.76 & 83.9630 \\
\hline 7 & 13 & 0.2 & 10 & 98.990 & 93.040 & 96.27 & 91.0614 \\
\hline 8 & 24 & 0.6 & 10 & 98.230 & 99.102 & 96.02 & 97.3299 \\
\hline 9 & 2 & 0.6 & 10 & 98.160 & 99.483 & 95.56 & 95.9626 \\
\hline 10 & 2 & 0.6 & 100 & 63.248 & 62.376 & 50.14 & 48.8301 \\
\hline 11 & 13 & 1.0 & 10 & 99.060 & 102.815 & 96.19 & 99.6861 \\
\hline 12 & 13 & 0.2 & 100 & 44.380 & 40.625 & 33.14 & 29.9139 \\
\hline 13 & 24 & 0.6 & 100 & 63.760 & 62.437 & 49.97 & 49.5674 \\
\hline 14 & 13 & 0.6 & 55 & 82.490 & 82.490 & 65.67 & 65.6700 \\
\hline 15 & 13 & 1.0 & 100 & 75.510 & 81.460 & 60.73 & 65.9386 \\
\hline
\end{tabular}

The above table shows the observed and predicted values. The percentage of adsorption of lead increases from 44.38 to 99.060 . Maximum adsorption is 99.060 and occurs at concentration of lead 10ppm, time 13 hours and adsorbate concentration of 1 gram and it is well agreed with predicted value of 102.759 for coir pith.

The percentage of adsorption of lead increases from 33.41 to 96.27. Maximum adsorption is 96.27 and occurs at concentration of lead 10ppm, time 13 hours and adsorbate concentration of 0.2 gram and it is well agreed with predicted value of 91.0625 peanut shells. 
Response Surface regression: D versus A B C

Table 4: Analysis of variance

\begin{tabular}{|c|c|c|c|c|c|c|}
\hline Source & DF & Adj SS & Adj MS & f-value & p-value & remarks \\
\hline Coir pith & 9 & 4471.42 & 496.82 & 12.52 & 0.006 & significant \\
\hline Linear & 3 & 4001.82 & 1333.94 & 33.62 & 0.001 & significant \\
\hline A & 1 & 0.05 & 0.05 & 0.00 & 0.973 & \\
\hline $\mathrm{B}$ & 1 & 1280.69 & 1280.69 & 32.27 & 0.002 & significant \\
\hline $\mathrm{C}$ & 1 & 2721.08 & 2721.08 & 68.57 & 0.000 & significant \\
\hline Square & 3 & 227.96 & 75.99 & 1.91 & 0.245 & ............ \\
\hline $\mathrm{A}^{*} \mathrm{~A}$ & 1 & 72.067 & 2.06 & 1.82 & 0.236 & ............ \\
\hline $\mathrm{B} * \mathrm{~B}$ & 1 & 123.45 & 123.45 & 3.11 & 0.138 & \\
\hline $\mathrm{C} * \mathrm{C}$ & 1 & 28.48 & 28.48 & 0.72 & 0.436 & ............. \\
\hline 2-Way Interaction & 3 & 241.64 & 80.55 & 2.03 & 0.228 & ב..... \\
\hline $\mathrm{A} * \mathrm{~B}$ & 1 & 0.41 & 0.41 & 0.01 & 0.923 & ............ \\
\hline $\mathrm{A} * \mathrm{C}$ & 1 & 0.05 & 0.05 & 0.00 & 0.973 & \\
\hline $\mathrm{B} * \mathrm{C}$ & 1 & 241.18 & 241.18 & 6.08 & 0.057 & ............ \\
\hline Error & 5 & 198.41 & 39.68 & & 2 & \\
\hline Lack-of-fit & 3 & 198.41 & 66.14 & e & & \\
\hline Pure error & 2 & 0.00 & 0.00 & & 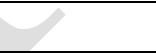 & \\
\hline Total & 14 & 4669.83 & & & & \\
\hline Peanut ShellModel & 9 & 5796.80 & 644.09 & 20.25 & 0.002 & significant \\
\hline Linear & 3 & 5501.53 & 1833.84 & 57.65 & 0.000 & significant \\
\hline A & 1 & 2.21 & 2.21 & 0.07 & 0.802 & \\
\hline B & 1 & 996.79 & 996.79 & 31.33 & 0.003 & significant \\
\hline $\mathrm{C}$ & 1 & 4502.53 & 4502.53 & 141.54 & 0.000 & significant \\
\hline Square & 3 & 107.45 & 35.82 & 1.13 & 0.422 & $\ldots \ldots \ldots \ldots$ \\
\hline$A * A$ & 1 & 56.26 & 56.26 & 1.77 & 0.241 & …......... \\
\hline $\mathrm{B} * \mathrm{~B}$ & 1 & 25.56 & 25.56 & 0.80 & 0.411 & ............. \\
\hline $\mathrm{C}^{*} \mathrm{C}$ & 1 & 41.41 & 41.41 & 1.30 & 0.306 & ........... \\
\hline 2-Way Interaction & 3 & 187.81 & 62.60 & 1.97 & 0.237 & …........ \\
\hline $\mathrm{A} * \mathrm{~B}$ & 1 & 0.02 & 0.02 & 0.00 & 0.981 & \\
\hline $\mathrm{A} * \mathrm{C}$ & 1 & 0.10 & 0.10 & 0.00 & 0.958 & .......... \\
\hline $\mathrm{B} * \mathrm{C}$ & 1 & 187.69 & 187.69 & 5.90 & 0.059 & \\
\hline Error & 5 & 159.06 & 31.81 & & & \\
\hline Lack-of-Fit & 3 & 159.06 & 53.02 & & & \\
\hline Pure Error & 2 & 0.00 & 0.00 & & & \\
\hline Total & 14 & 5955.85 & & & & \\
\hline
\end{tabular}

The larger the value of $\mathrm{F}$ and smaller the value of $\mathrm{P}$, more is the significant of the model. In the analysis of variance if the value of $\mathrm{p}$ is less than 0.05 then it indicates that the model is significant. For the removal of lead, the ANOVA result showed that the value of $F$ for the model is 12.76 and 20.25 for coir pith and peanut shell respectively, implying that the model is significant. In the present study the values which are less than 0.05 were significant factors. The other factors in the model which are greater than 0.05are not significant (A.Igder et., al 2012). 
Table 5(a): Model Summary (Coir Pith)

\begin{tabular}{|c|c|c|c|}
\hline S & R-sq & R-sq(adj) & R-sq(pred) \\
\hline 6.29939 & $95.75 \%$ & $88.10 \%$ & $32.02 \%$ \\
\hline
\end{tabular}

The fitting of the experimental data to the regression model is checked by adjusted $\mathrm{R}^{2}$ $\left(\mathrm{R}^{2}=0.8832\right)$ which means that $88.32 \%$ of the total variation of adsorption on the experimental data by the response surface methodology (Ali Fakhri et., al 2013).

Table 5(b): Model Summary (Peanut Shell)

\begin{tabular}{|c|c|c|c|}
\hline S & R-sq & R-sq(adj) & R-sq(pred) \\
\hline 5.64016 & $97.33 \%$ & $92.52 \%$ & $57.27 \%$ \\
\hline
\end{tabular}

The fitting of the experimental data to the regression model is checked by adjusted $\mathrm{R}^{2}$ $\left(\mathrm{R}^{2}=0.9253\right)$ which means that $92.53 \%$ of the total variation of adsorption on the experimental data by the response surface methodology (Ali Fakhri et., al 2013).

Table 6: Coded Coefficients

\section{Coir pith}

\begin{tabular}{|l|l|l|l|l|l|l|}
\hline Term & Effect & Coef & SE Coef & T-Value & P-Value & VIF \\
\hline Constant & & 82.49 & 3.60 & 22.94 & 0.000 & \\
\hline A & -0.05 & -0.02 & 2.20 & -0.01 & 0.992 & 1.00 \\
\hline B & 25.19 & 12.60 & 2.20 & 5.72 & 0.002 & 1.00 \\
\hline C & -36.89 & -18.44 & 2.20 & -8.38 & 0.000 & 1.00 \\
\hline A*A & -8.72 & -4.36 & 3.24 & -1.35 & 0.236 & 1.01 \\
\hline B*B & -11.45 & -5.73 & 3.24 & -1.77 & 0.138 & 1.01 \\
\hline C*C & 5.44 & 2.72 & 3.24 & 0.84 & 0.439 & 1.01 \\
\hline A*B & 0.41 & 0.21 & 3.11 & 0.07 & 0.949 & 1.00 \\
\hline A*C & 0.22 & 0.11 & 3.11 & 0.04 & 0.973 & 1.00 \\
\hline B*C & 15.53 & 7.77 & 3.11 & 2.49 & 0.055 & 1.00 \\
\hline
\end{tabular}

\section{Peanut shell}

\begin{tabular}{|l|c|l|l|l|l|l|}
\hline Term & Effect & Coef & SE Coef & T-Value & P-Value & VIF \\
\hline Constant & & 65.67 & 3.26 & 20.17 & 0.000 & \\
\hline A & 1.05 & 0.52 & 1.99 & 0.26 & 0.803 & 1.00 \\
\hline B & 22.32 & 11.16 & 1.99 & 5.60 & 0.003 & 1.00 \\
\hline C & -47.45 & -23.72 & 1.99 & -11.90 & 0.000 & 1.00 \\
\hline A*A & 7.81 & 3.90 & 2.93 & 1.33 & 0.241 & 1.01 \\
\hline B*B & 5.26 & 2.63 & 2.93 & 0.90 & 0.411 & 1.01 \\
\hline $\mathrm{C}^{*} \mathrm{C}$ & 6.70 & 3.35 & 2.93 & 1.14 & 0.305 & 1.01 \\
\hline $\mathrm{A}^{*} \mathrm{~B}$ & 0.14 & 0.07 & 2.82 & 0.02 & 0.982 & 1.00 \\
\hline $\mathrm{A}$ C & -0.32 & -0.16 & 2.82 & -0.06 & 0.958 & 1.00 \\
\hline $\mathrm{B} * \mathrm{C}$ & 13.70 & 6.85 & 2.82 & 2.43 & 0.059 & 1.00 \\
\hline
\end{tabular}


If the p-value of a constant is a smaller amount than the chosen significance level, such as 0.05, the connection between the predictors and therefore the response is statistically vital. Minitab conjointly includes a worth for the constant within the equation within the Coef column.

Regression Equation in Uncoded Units

The regression analysis is done to fit response. The developed regression model represents the function of time, concentration of lead and amount of adsorbents. The relationship between the response and input variables is expressed by following quadratic equation

\section{Coir pith}

$\mathrm{D}=86.1+0.886 \mathrm{~A}+50.3 \mathrm{~B}-0.822 \mathrm{C}-0.0365 \mathrm{~A} * \mathrm{~A}-36.1 \mathrm{~B} * \mathrm{~B}+0.00137 \mathrm{C} * \mathrm{C}$

$+0.073 \mathrm{~A} * \mathrm{~B}+0.00022 \mathrm{~A} * \mathrm{C}+0.431 \mathrm{~B} *$

\section{Peanut shell}

$\mathrm{D}=106.1-0.783 \mathrm{~A}-13.0 \mathrm{~B}-0.933 \mathrm{C}+0.0323 \mathrm{~A} * \mathrm{~A}+16.4 \mathrm{~B} * \mathrm{~B}+0.00165 \mathrm{C} * \mathrm{C}$

$$
+0.016 \mathrm{~A} * \mathrm{~B}-0.00032 \mathrm{~A} * \mathrm{C}+0.381 \mathrm{~B} * \mathrm{C}
$$

The above equations showed that how the individual variables and double interaction affect the adsorption of lead on the coir pith and peanut shell. The negative coefficient indicates that the factors negatively affect lead adsorption. Whereas positive coefficients affects positively on the lead adsorption (Biswajit Das et., al 2013).

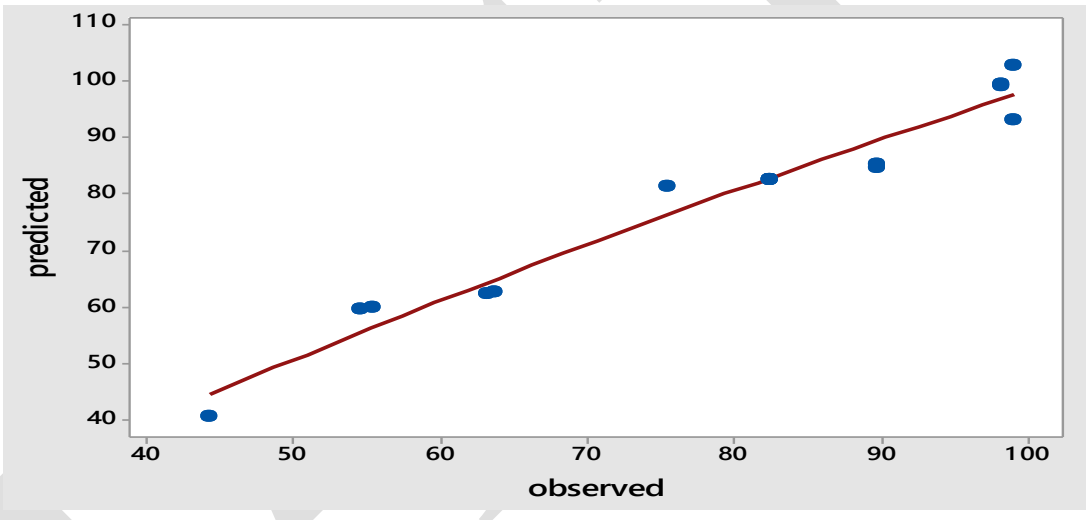

Fig (1) Regression model for coir pith

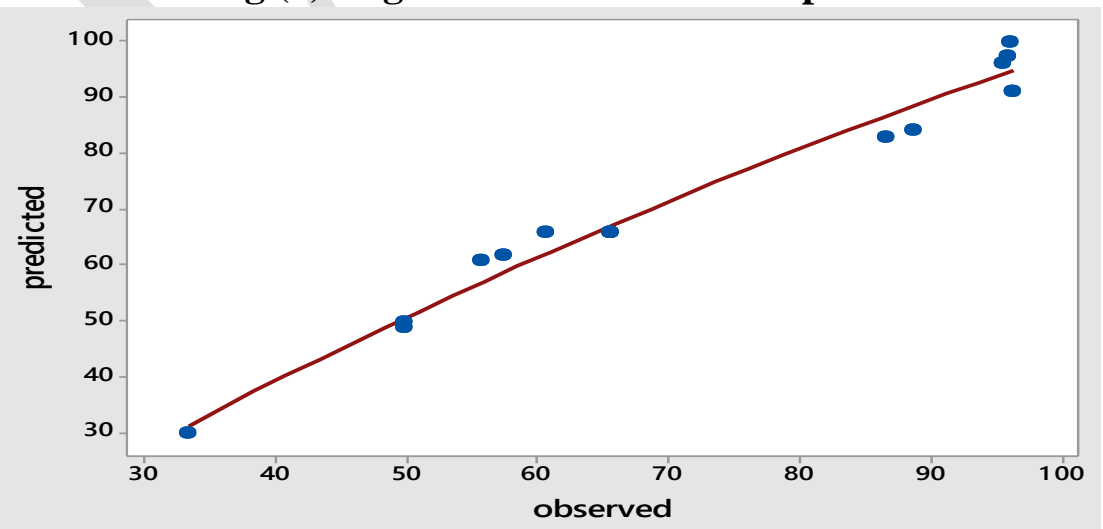

Fig (2) Regression model for peanut shell

The above figure shows that the data points are very nearly distributed to the straight line it indicates the actual relationship among observed and predicted values. 


\section{Contour plots Coir pith}

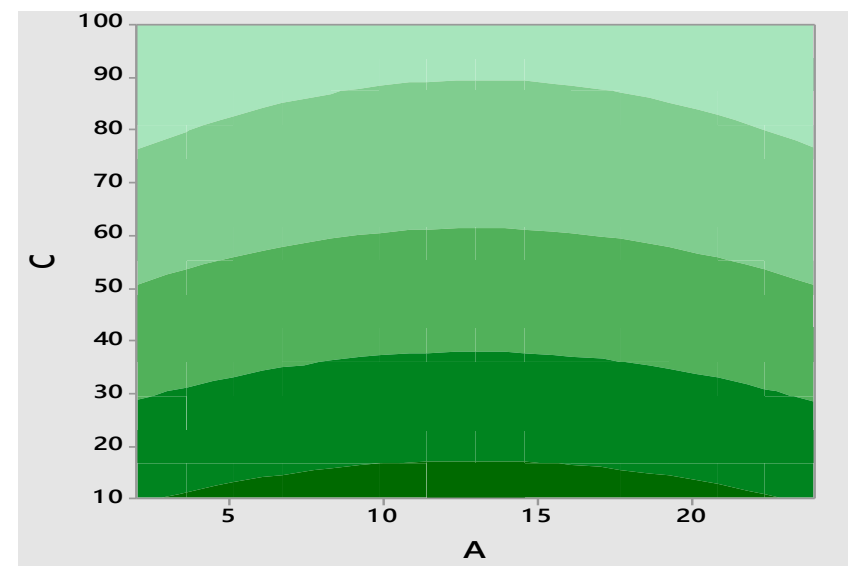

Fig (3(a)) Time with concentration of adsorbate

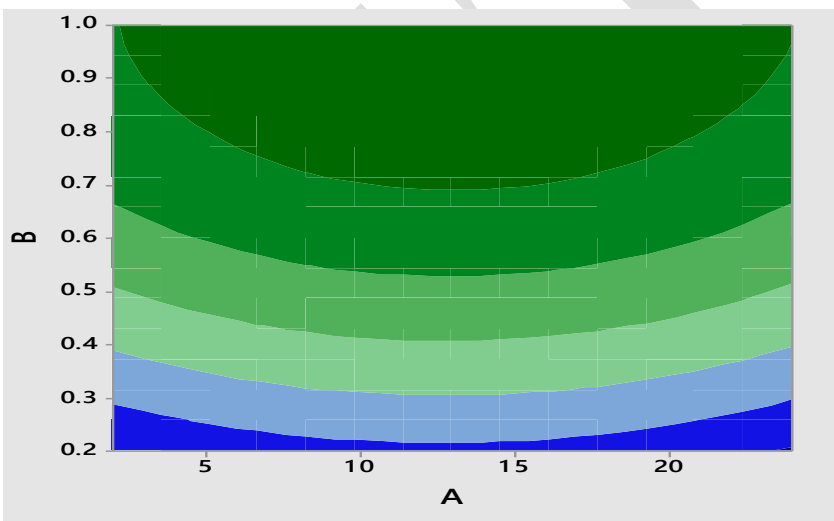

Fig (3(b) Time with concentration adsorbent

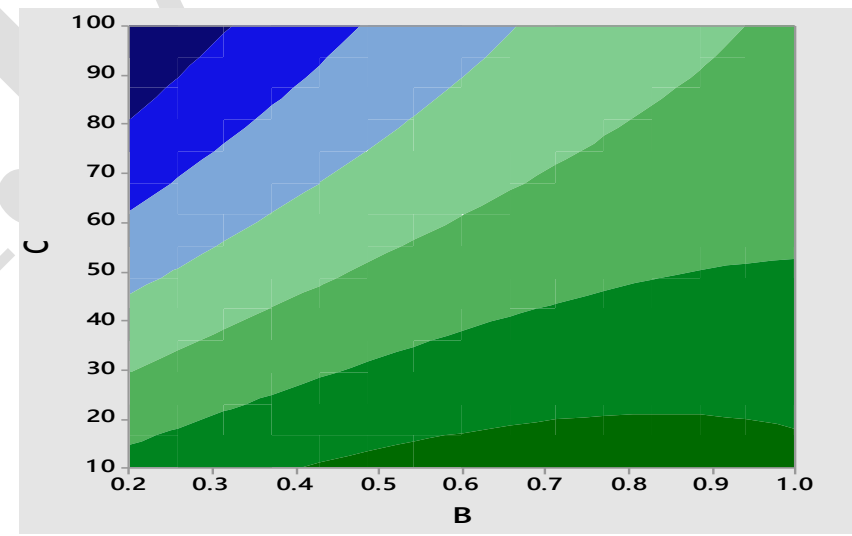

Fig (3(c)) Amount of adsorbent with concentration adsorbate

In fig (3(a)) Darker region indicates the higher removal efficiency. The above graph is drawn by comparing response with time on $\mathrm{X}$ axis and initial concentration of lead on $\mathrm{Y}$ axis. The removal efficiency of lead increases with decreasing the concentration of lead.In fig (3(b)) shows that 
relation between the concentration of adsorbent and time, as the concentration of adsorbent increases the \% of removal increases.Fig (3(c)) is drawn in comparison with amount of adsorbent and concentration of lead. As the concentration of the lead decreases with increase in the adsorbent amount the efficiency of removal also increases (Biswajit Das et., al 2013).

\section{Surface plots for coirpith}

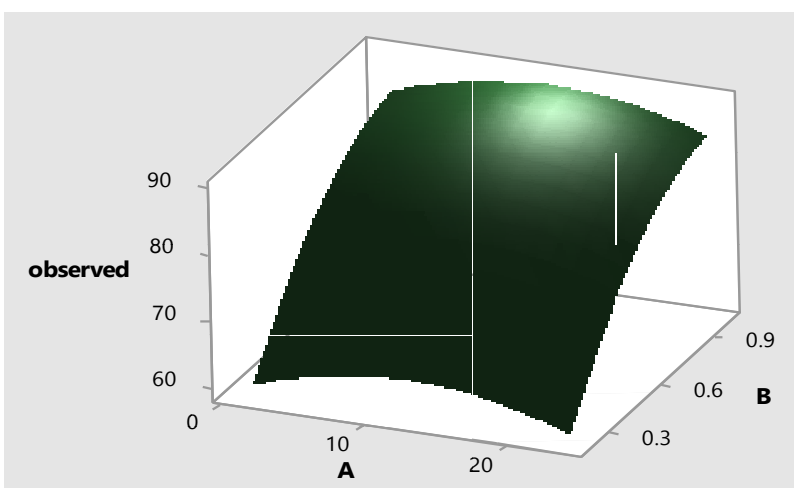

Fig (4(a) Time with Amount of adsorbent

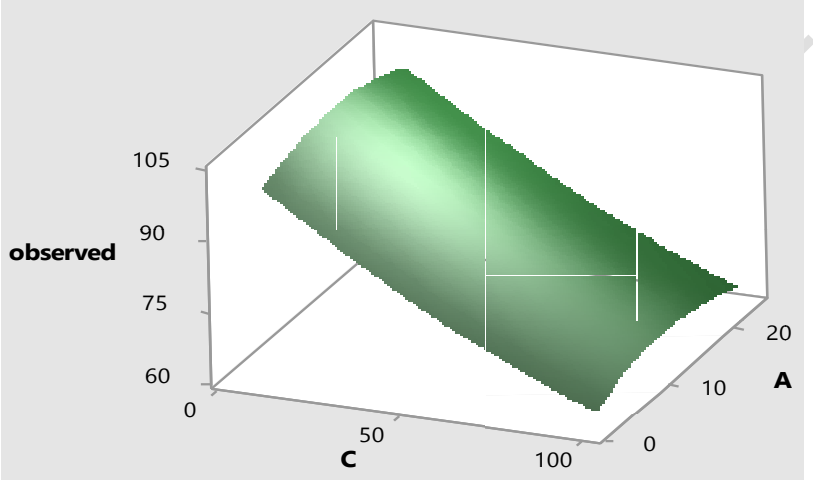

Fig (4(b)) Time with concentration of adsorbate

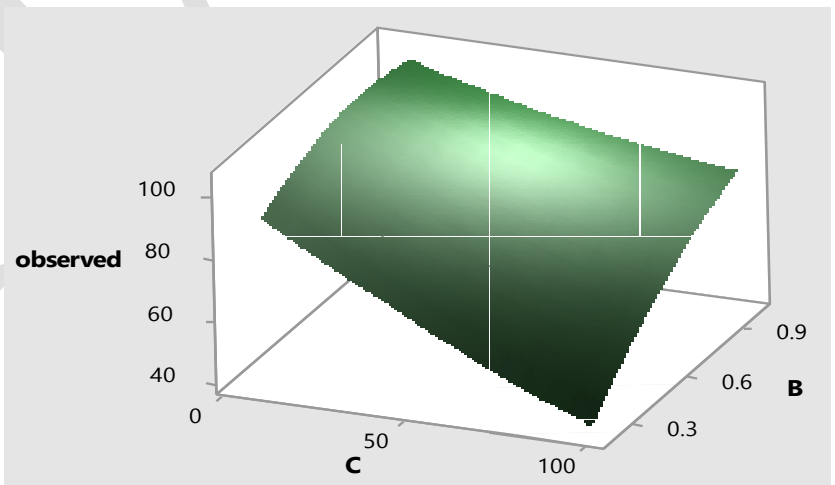

Fig (4(c)) Amount of adsorbent with concentration adsorbate

In fig (4(a)) showed that as the concentration of lead decreases with increase in time the removal efficiency of lead increases. In fig (4(b) removal efficiency increases with decreases in the concentration of lead and by increases in the contact time.In fig (4(c)) the efficiency of removal 
increase with decreases on concentration of lead and by increases in the amount of adsorbent (Darapureddi Krishna et., al 2014).

\section{Contour plots for Peanut Shell}

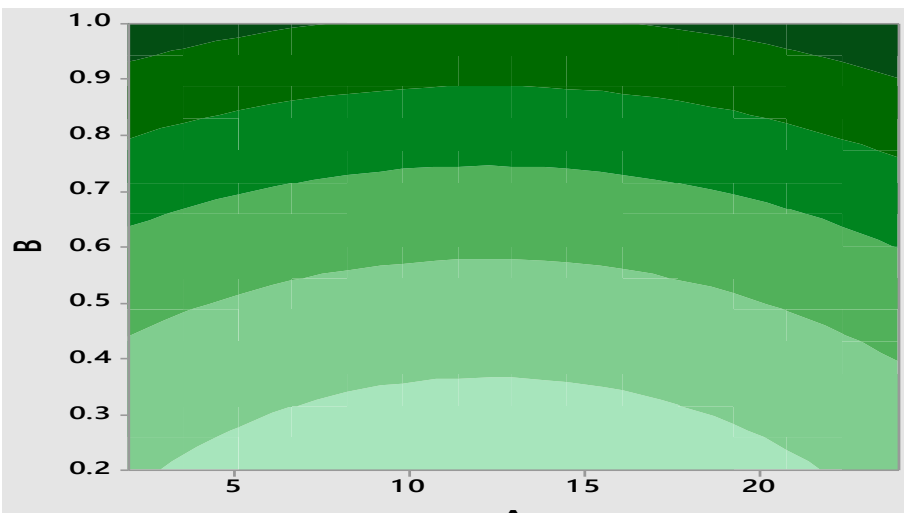

Fig (5(a) Time with amount of adsorbent

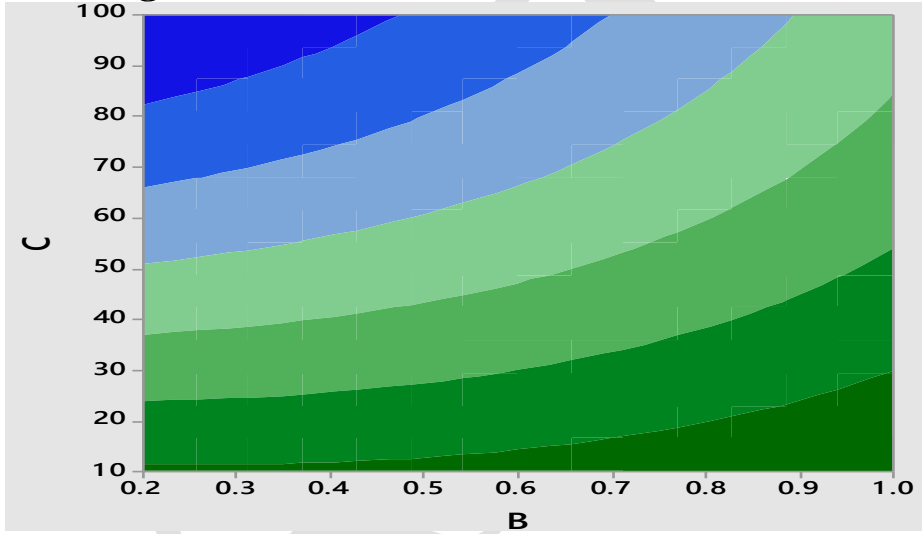

Fig (5(b)) Amount of adsorbent with concentration of adsorbate

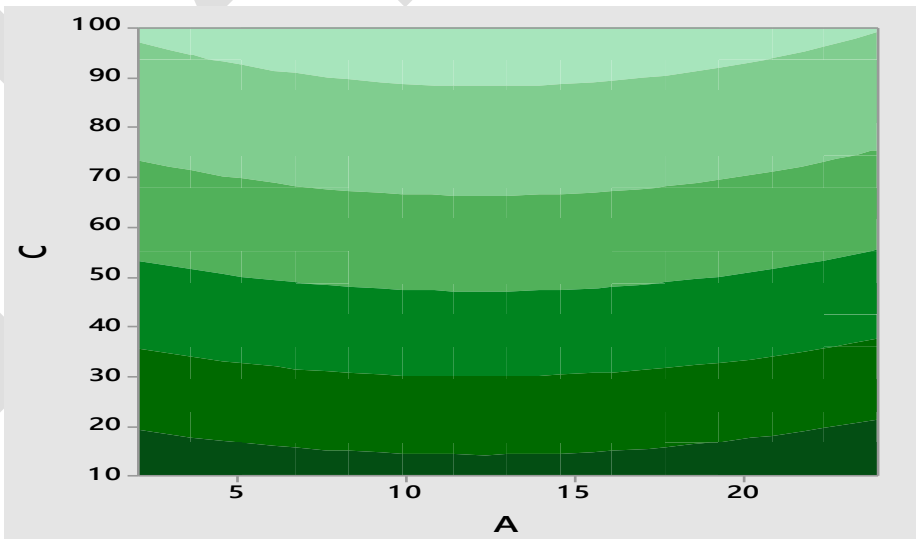

Fig (5(c)) Time with concentration of adsorbate

In fig (5(a)) Removal efficiency increase with increase in the concentration of lead and with increase in the time.In fig (5(b)) Removal efficiency increases with increases in amount of adsorbent and by decreases in the concentration of lead.In fig (5(c)) Removal efficiency 
increases with decrease in the concentration of lead and by increase in time(Biswajit Das et., al 2013).

\section{Surface plots for peanut shell}

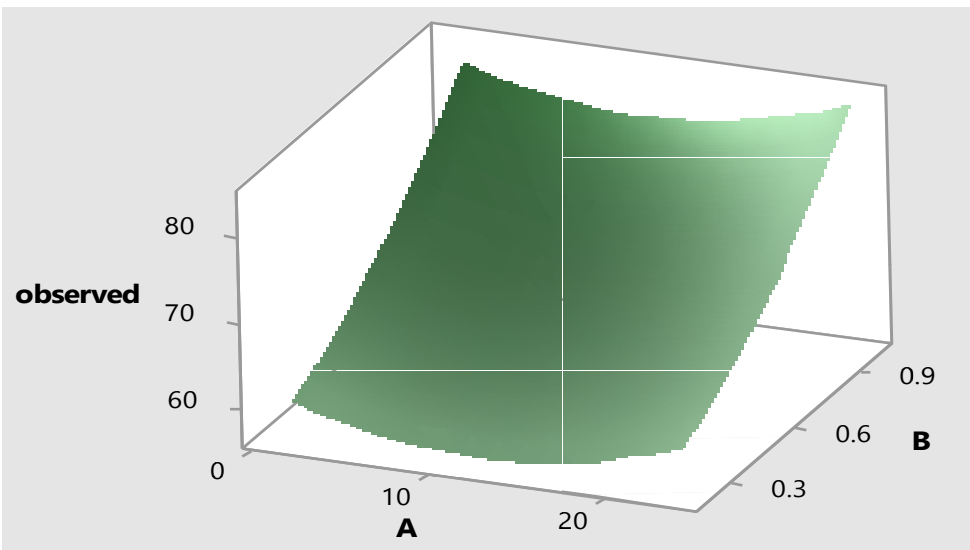

Fig (6(a)) Time with amount of adsorbent

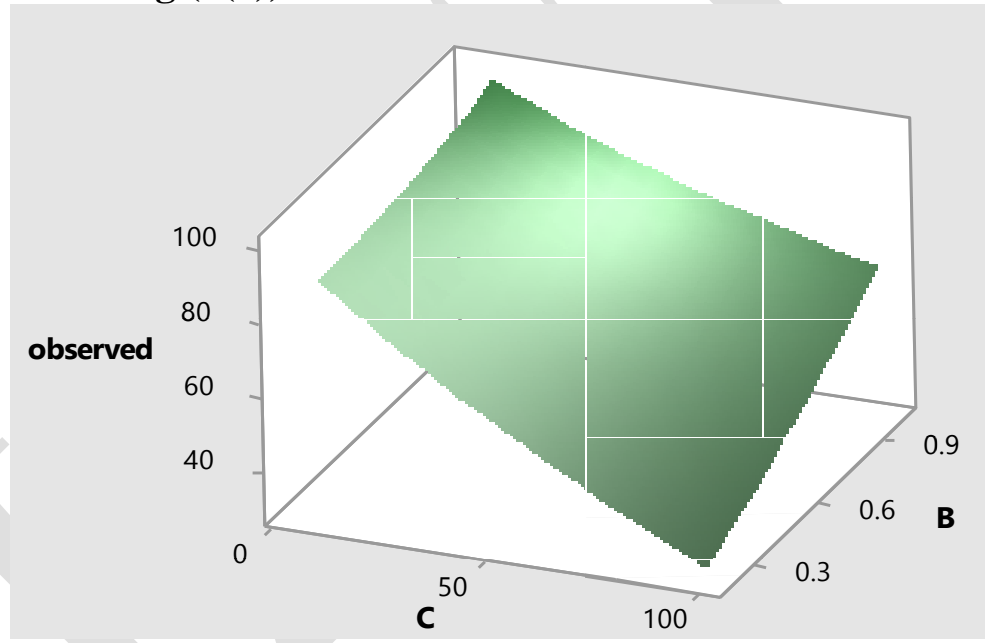

Fig (6(b) Amount of adsorbent and concentration of adsorbate

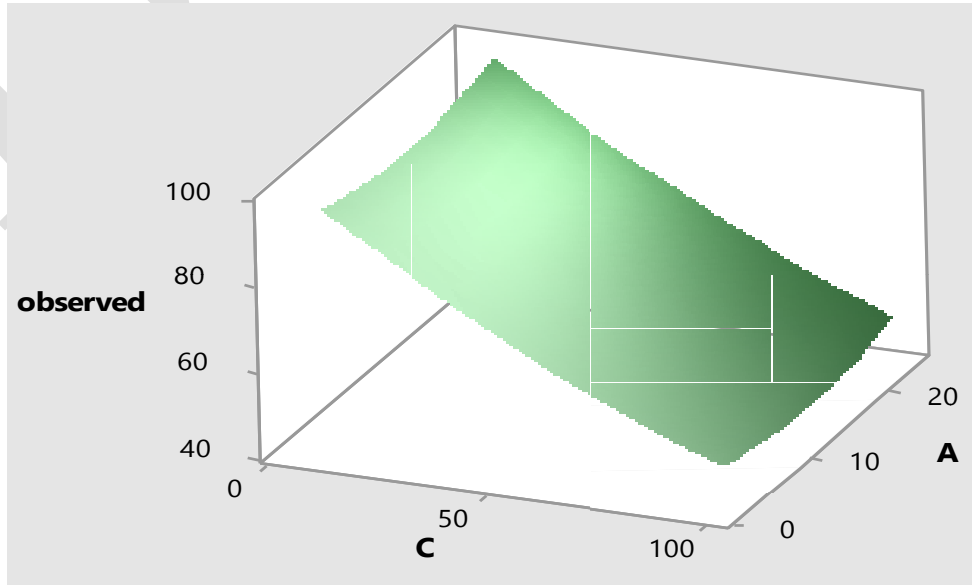

Fig $(6(c))$ Time with concentration adsorbate 
In fig (6(a)) Removal efficiency increases with increase in the amount of adsorbent and time.In fig (6(b)) Efficiency increases with increase in the amount of adsorbent and by decreasing the concentration lead. In fig (6(c)) Efficiency increases with increases in time and by decrease in concentration of lead.

Table No 8: Comparison between coir pith and peanut shell

\begin{tabular}{|l|l|l|l|l|l|}
\hline A & B & C & $\begin{array}{l}\text { \%removal } \\
\text { Coir pith }\end{array}$ & $\begin{array}{l}\text { \% removal } \\
\text { peanut shell }\end{array}$ & $\begin{array}{l}\text { Remarks } \\
\text { efficient } \\
\text { adsorbent }\end{array}$ \\
\hline 2 & 1.0 & 55 & 89.78 & 86.67 & coir pith \\
\hline 13 & 0.6 & 55 & 82.49 & 65.67 & coir pith \\
\hline 13 & 1.0 & 100 & 75.51 & 60.73 & coir pith \\
\hline 13 & 1.0 & 10 & 99.06 & 96.19 & coir pith \\
\hline 2 & 0.6 & 10 & 98.16 & 95.56 & Coir pith \\
\hline 13 & 0.2 & 10 & 98.99 & 96.27 & Coir pith \\
\hline 13 & 0.6 & 55 & 82.49 & 65.67 & coir pith \\
\hline 2 & 0.6 & 100 & 63.248 & 50.14 & Coir pith \\
\hline 24 & 0.6 & 10 & 98.16 & 96.02 & Coir pith \\
\hline 13 & 0.6 & 55 & 82.49 & 65.67 & coir pith \\
\hline 24 & 0.6 & 100 & 63.76 & 49.97 & Coir pith \\
\hline 24 & 0.2 & 55 & 54.16 & 57.6 & peanut shell \\
\hline 2 & 0.2 & 55 & 55.41 & 55.78 & peanut shell \\
\hline 24 & 1.0 & 55 & 89.81 & 88.76 & Coir pith \\
\hline 13 & 0.2 & 100 & 44.38 & 33.41 & Coir pith \\
\hline
\end{tabular}

The above table shows the comparison between the adsorbents. From the above table it is clear that coir pith has more adsorption capacity for adsorbing lead from aqueous solution than peanut shell.

\section{CONCLUSION}

Response surface methodology was useful for the adsorption of lead from this quadratic model was developed to co relate the variables to the response. The predicted values obtained from the design are well agreed with the observed values. Coir pith shows the more adsorption capacity of lead when compared to peanut shell.

\section{REFERENCE}

1. Shakwri, Abollfazl; Hazeri, Nourallah, valizadeh, Jafar, Hashemi, Esmail, MotavalizadehKakhaky, Ali Reza, Removal of lead (II) from aqueous solution using Cocopeat; an investigation on the isotherm and kinetics Vol.31,No.3,2012..

2. Pradeepkumar, RamamohanRao, Shri Chand, Sushil Kumar, K.L. Wasewar, Chang KyooYoo, Adsorption of lead from aqueous solution onto coir-pith activated 
corbon.2012.

3. Mambo Moyo, Linda Chikazaza, Bioremediation of Lead(II) from Polluted Wastewaters Employing Sulphuric Acid Treated Maize Tassel Biomass.

4. Neeta Singh, Dr.S.K.Gupta, International journal of Innovative Research in Science,Engineering and Technology Vol.5,Issue 2, February 2016.

5. I.E.Agbozu and F.O. Emoruwa, Batch adsorption of heavy metals $(\mathrm{Cu}, \mathrm{Pb}, \mathrm{Fe}, \mathrm{Cr}$ and $\mathrm{Cd})$ from aqueous solution using coconut husk Vol.8(4),pp.239-246,April 2014

6. Lokendra Singh Thakur,PradeeoSemil, adsorption of heavy metal $\left(\mathrm{Cd}^{2+}, \mathrm{Cr}^{6+}\right.$ and $\mathrm{Pb}^{2+}$ )from synthetic waste water by coconut husk adsorbent Volume 1 Issue 4 ..

7. SarifahFauziah Syed Draman, NorzilaMohd, Nor HafizaIzzatiWahab, NurulSyahirahZulkfli and Nor FatinAdila Abu Bakar, Adsorption of lead (II) ions in aqueous solution using selected agro -waste Vol.10,No.1, January 2015..

8. Prabha R.T, Dr.Udayashankara T.H., Removal of heavy metal from synthetic wastewater using rice husk and groundut shell as adsorbents Vol.8 Issue 7 Ver,II(july.2014),PP 2634.

9. PARK Heung Jai, JEONG SeongWook, YANG Jae Kyu, KIM Boo Gil, LEE SeungMok, Removal of heavy metals using waste eggshell.

10. OkonOkon, UbongEduok and Aniekeme-AbasiIsrel, Characterization and phytochemical screening of coconut (cocosnucifera L) coir dust as a low cost adsorbent for waste water treatment ElixirAppl.Chem.47(2012)8961-8968..

11. W.S Wan Ngah, M.A.K.M. Hanafiah, Removal of heavy metal ions from wastewater by chemically modified plant wastes as adsorbents BioresourseTeechnology 99(2008)3935, 2007.

12. NordianaSuhadaMohmadTahiruddin and SitiZubaidahAbRahman, Adsorption of lead in aqueous solution by a mixture of activated charcoal and peanut shell Vol.1, No. 5, July 2013, PP:102109, ISSN:2329-3837.

13. Mohammad aliZazouli ,Farzanehveisi, Amir veisi, Modelling of Bisphenol A (BPA) removal from aqueous solution by adsorption using response surface methodology.

14. J.Aravand, C.Lenin, C. Nancyflavia, P.Rashika, S.Saravanan, Response surface methodology optimization of nickel(II) removal using pigeon pea pod bioadsorbent. Int.J.Environ.Sci.Technol.(2015)12:105-114. 
15. F.D,Oliveria, J.H.Paula, O.M. Freitas, S.A.Figueiredo, Copper and lead removal by peanut hulls:Equillibrium and kinetic studies.

16. A.A.Essiette. U.Israel, S.O.Uwak, A.B. Udoimuk and Ekpo, M.E, Adsorption approach for recovery and removal of $\mathrm{Cd}(\mathrm{II})$ from aqueous solution using coir dust, Archives of Applied Science Research,2011,3(6):402-412.

17. SeydaTasar, Fatih Kaya, AhmetOzer, Biosorption of lead (II) ions from Aqueous solution by peanut shells: Equillibrium, thermodynamic and kinetic studies Journal of environmental chemical engineering 2(2014)1018-1026.

18. K.K. Singh, M. Talat, S.H. Hasan, Removal of lead from aqueous solutions by agricultural waste maize bran Bioresource Technology 97 (2006) 2124-2130.A

19. A.Igder, Ali Akbar Rahmani, Ali Fazlavi, Mohammad HosseinAhmadiAzqhandi, Mohammad Hassan Omidi, Box-Behnken Design of experiments investigation for adsorption of $\mathrm{Cd}^{2+}$ onto carboxymethyl Chitosan Magnetic Nanoparticles, Vol 3, No.1,2012, 51-59.

20. Ali Fakhri and SaeidehAdami, Response surfsce methodology for adsorption of fluoride ion using nanopaeticles of zero valent iron from aqueous solution, volume 4,2013.

21. Biswajit Das, Naba Kumar Mondal, Palas Roy and Soumyachattoraj, Application of response surface methodology for hexavalent chromium adsorption onto alluvial soil of Indian origin,(2013)2:72-87.

22. Darapureddi Krishna and R.PadmaSree, Response surface modeling and optimization of $\mathrm{Cu}$ (II) removal from waste water using BorasusFlabellifer Coir piwder, Int.J.Appl.Sci.Eng.,2014.12,3:157-167. 